\title{
Studi penggunaan PhET Interactive Simulations dalam pembelajaran fisika
}

\author{
Astalini \\ Pendidikan Fisika, Universitas Jambi, Indonesia \\ Surat-e: astalinizakir@unja.ac.id \\ Darmaji \\ Pendidikan Fisika, Universitas Jambi, Indonesia \\ Surat-e: darmaji@unja.ac.id \\ Cicyn Riantoni \\ Pendidikan Fisika, Universitas Jambi, Indonesia \\ Surat-e: cicynriantoni12@gmail.com \\ Nova Susanti \\ Pendidikan Fisika, Universitas Jambi, Indonesia \\ Surat-e: nova_fisikaunja@unja.ac.id
}

\begin{abstract}
Abstrak. Artikel ini bertujuan untuk menjelaskan pengunaan PhET Interactive Simulations sebagai pendukung maupun penganti laboratorium real dalam pembelajaran fisika. Adapun topik yang diangkat meliputi apa itu PhET interactive simulation, kegunaan PhET interactive simulation dalam pembelajaran fisika dan pengaruh pengunaan Phet Interactive Simulation dalam pembelajaran fisika dibanding laboratorium Real. Analisis data dilakukan dengan meeduksi data berdasarkan pertanyaan penelitian dan kemudian dilakukan pengkodean sesuai kebutuhan. Berdasarkan hasil studi literatur didapatkan bahwa PhET merupakan sebuah simulasi yang dikembangkan oleh Universitas Colorado yang difokuskan pada pembelajaran fisika yang menekankan korespondensi antara fenomena nyata dan simulasi komputer kemudian menyajikannya dalam model-model konseptual fisis yang mudah dimengerti oleh para peserta didik. Simulasi ini dapat membantu peserta didik maupun peserta didik dalam mengenal topik baru, membangun konsep atau skill, memperkuat ide, menyediakan hasil akhir dan refleksi serta menyediakan visualisasi umum antara peserta didik dan guru. Selain itu juga hasil dari beberapa penelitian menunjukkan bahwa pengunaan PhET memberikan pengaruh yang berbeda dari segi penguasaan konsep, hasil belajar dan kemampuan pemecahan masalah peserta didik, karena PhET dapat menjelaskan konsep yang abstrak dan dalam pengunaannya tidak memerlukan waktu yang banyak.
\end{abstract}

Kata kunci: PhET, Pembelajaran Fisika

\begin{abstract}
This article aims to explain the use of PhET Interactive Simulations as supporters and substitutes for real laboratories in learning physics. The topics raised include what is PhET interactive simulation, the use of PhET interactive simulation in learning physics and the effect of using Phet Interactive Simulation in learning physics compared to the Real laboratory. Data analysis was performed by reducing data based on research questions and then coding them as needed. Based on the results of the literature study it was found that PhET is a simulation developed by the University of Colorado that is focused on learning physics that emphasizes the correspondence between real phenomena and computer simulations and then presents it in physical conceptual models that are easily understood by students. This simulation can help students and students recognize new topics, develop concepts or skills, strengthen ideas, provide final results and reflections and provide general visualization between students and teachers. In addition, the results of several studies indicate that the use of PhET gives different effects in terms of mastery of concepts, learning outcomes and students' problem solving abilities, because PhET can explain abstract concepts and their use does not require a lot of time.
\end{abstract}

Keywords: PhET, physics learning 


\section{Pendahuluan}

Pembelajaran fisika merupakan pembelajaran yang sangat berhubungan dengan segala aktivitas manusia dalam kehidupan sehari-hari. Hal itulah yang menyebabkan sebelum peserta didik belajar secara formal di lingkungan sekolah, peserta didik sudah memiliki banyak pengalaman yang relevan tentang pembelajaran fisika. Mereka sudah berinteraksi dengan dunia fisik dan berbicara tentang dunia fisika sebagai wacana dalam kehiduan sehari-hari [1].

Pengalaman dan pengetahuan awal yang dibawa peserta didik sebelum belajar selain memberikan kemudahan kepada peserta didik juga tidak sedikit memberikan pengaruh konsepsi dalam pemikiran peserta didik.Hal ini sesuai dengan pernyaataan [2] bahwa banyak peserta didik setelah pembelajaran masih memegang kuat dan masih mengunakan pemahaman awal yang salah dalam memecahkan masalah sehingga menyebabkan kesalahan konsep. Selain itu juga sebagian besar peserta didik mengangap pembelajaran fisika merupakan pembelajaran yang sulit karena materi yang bersifat abstrak [3], memerlukan ketepatan dalam pemecahan masalah dan skill matematika [3][4].

Salah satu faktor yang menjadi penyebab kesulitan peserta didik dalam memahami materi fisika adalah pembelajaran yang masih kurang menekankan peran aktif peserta didik. Pembelajaran seharusnya mampu menciptakan lingkungan yang dapat membantu peserta didik memahami konsep [5][6] dan proses sains [5]. National Reseach Council (NRC) mengindikasikan bahwa interaksi sosial dan interaksi fisikal diperlukan untuk sumber pengetahuan saintifik dan untuk memahami ilmu pengetahuan alam [7][8].

Dalam mengatasi kesulitan peserta didik dalam pembelajaran fisika dapat dilakukan dengan bantuan laboratorium virtual [9][10][11]. Laboratorium virtual terbuki memberikan efek yang positif terhadap perkembangan skil peserta didik, sikap [12] dan pemahaman konsep [9][12] [11]. Laboratorium virtual dapat sebagai pendukung dalam mengembangkan dan merubah konseptual dan membantu peserta didik untuk memahami fenomena fisik dalam berbagai lingkup pembelajaran fisika [13]. Laboratorium virtual dapat menggantikan perlengkapan laboratorium fisik dalam mengumpulkan, menunjukan data dan menyajikan sebuah medium untuk komunikasi dan kordinasi serta sebagai bantuan pembelajaran yang dapat membantu peserta didik dalam memahami konsep dan menyatukan pengetahuan [14].

Dalam beberapa dekade terakhir ini telah banyak keyakinan tentang potensial dari realita virtual untuk menunjang belajar dan pembelajaran dalam laborotorium sains [12]. Beberapa judul penelitian yang telah diangkat seperti ketika pembelajaran tentang dunia nyata lebih baik dilakukan dengan virtual, sebuah penelitian mengantikan simulasi komputer untuk peralatan laboratorium [15], penelitian tentang efek pemahaman konsep peserta didik tentang rangkaian listrik dengan memperkenalkan manipulasi virtual dalam sebuah pembelajaran fisika [11] dan masih banyak penelitian lainnya.

Beberapa penelitian telah mengungkapkan efek postif dari penggunaan PhET dalam pembelajaran. Oleh sebab itu artikel ini bermaksud untuk mengungkap: Apa itu PhET interactive simulation, kegunaan PhET interactive simulation dalam pembelajaran, pengaruh pengunaan Phet Interactive Simulation dalam pembelajaran Fisika dibanding laboratorium Real.

\section{Metode Penelitian}

Penelitian ini merupakan studi literatur. Pengumpulan data dilakukan dengan pengumpulan dokumen relevan dari berbagai sumber terkait dengan PhET Simulation, yaitu jurnal-jurnal bereputasi yang membahas $\mathrm{PhET}$. Analisis hasil penggumpulan data dilakukan dengan mereduksi data yang berkaitan denganpertanyaan penelitian dan selanjutnya dilakukan pengkodean. Pengkodean dilakukan terkait tiga hal, yaitu Apa itu PhET interactive simulation, kegunaan PhET interactive simulation dalam pembelajaran, pengaruh pengunaan Phet Interactive Simulation dalam pembelajaran Fisika dibanding laboratorium Real.

\section{Hasil Penelitian dan Pembahasan}

\section{Apa itu PhET Interactive Simulation}

PhET Interactive Simulations merupakan sebuah proyek di Universitas Colorado yang mengembangkan sebuah alat simulasi yang difokuskan pada pembelajaran fisika [9][15][16], namun demikian PhET juga menyediakan beberapa simulasi untuk pembelajan kimia [9][16], biologi, matematika dan sains lainya [16] yang mendapatkan keuntungan dari pengunaan komputer sebagai alat bantu pengunaanya seperti Gambar 1 . Simulasi ini menyediakan banyak setingan pembelajaran, meliputi aktivitas dosen, individual atau kelompok 
kecil, tugas rumah dan laboratorium [9]. PhET tumbuh dan berkembang dari simulasi kualitas profesional untuk belajar dan mengajar sains [17]. Simulasi tersebut menekankan korespondensi antarafenomena nyata dan simulasi komputer kemudian menyajikannyadalam model-model konseptual fisis yang mudah dimengerti olehparapeserta didik [9][14][17].

Simulasi PhET di bagi dalam beberapa kategori seperti gerak; usaha, energi dan daya; bunyi dan gelombang; kalor dan termodinamika; listrik dan rangkaian; cahaya dan radiasi; fenomena kuantum; kimia; alat matematika [16].

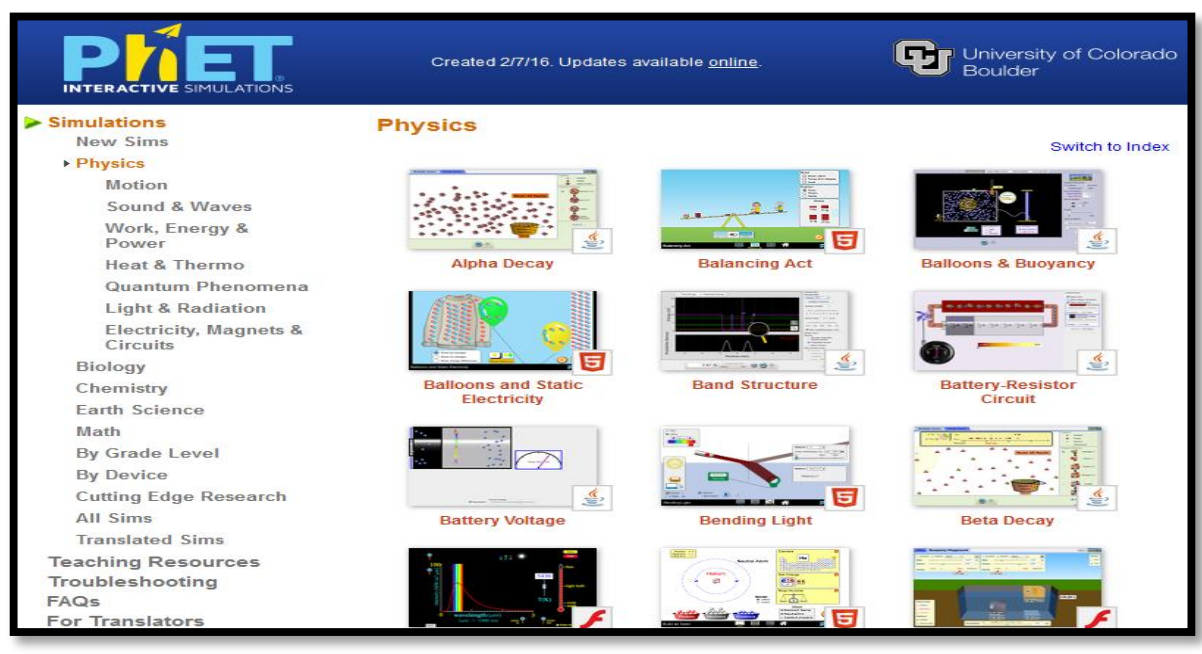

Gambar 1. Tampilan beberapa contoh simulasi dalam $\mathrm{PhET}$

\section{Kegunaan PhET Interactive Simulation dalam pembelajaran}

Dalam pembelajaran, PhET Interactive Simulations dapat membantu peserta didik maupun peserta didik dalam mengenal topik baru, membangun konsep atau skill, memperkuat ide, menyediakan hasil akhir dan refleksi serta menyediakan visualisasi umum antara peserta didik dan guru sehingga dapat menfasilitasi komunikasi dan pembelajaran [9]. Simulasi PhET dirancang untuk membangun hubungan antara pemahaman sehari-hari peserta didik dan prinsip-prinsip fisika yang mendasarinya, seringkali dengan media PhET modelmodel simulasi yang biasanya tidak terlihat oleh mata, seperti atom, elektron, foton, dan medan listrik menjadi terlihat [9][15-16].Selain itu juga Simulasi ini dirancang sangat interaktif , menarik, dan terbuka terhadap lingkungan sehingga memberikan animasi umpan balik untuk pengguna [15].

Kelebihan lain dari simulasi PhET adalah simulasi ini memberikan kesempatan kepada peserta didik untuk berinteraksi dengan visual dinamis, mengizinkan peserta didik untuk fokus dalam mengeksplorasikan inquiry, memberikan feed back yang cepat, memiliki banyak representasi [10], menghubungkan makroskopik, mikroskopik dan representasi simbolis [10]. Simulasi ini juga menciptakan sebuah pemahaman yang menyangkut sebuah visualisasidari fenomena dan banyak hubungan antar pengetahuan [16].

Dalam pemecahan masalah, bantuan PhET sebagai laboratorium virtual dapat meningkatkan akses peserta didik untuk menghasilkan konsep dan merepresentasikannya [15], serta memaksa peserta didik untuk produktif [15][18]. Selain itu juga laboratorium virtual lebih baik dari laboratorium real karena menyediakan respon yang tepat dan lebih mudah dalam membangun rangkaian [11]). Salah satu contoh penelitian mengunakan PhET adalah pada materi interferensi gelombang [19]. Hasil penelitian menghasilkan bahwa dengan PhET peserta didik dapat mengeksplore simulasi secara bebas dan intuitif, selain itu juga membuat peserta didik berpikir seperti seorang peneliti yang berguna untuk mempermudah dalam memahami ide-ide ilmiah [19].

\section{Pengaruh pengunaan PhET Interactive Simulation dalam pembelajaran fisika dibanding laboratorium real}

Berdasarkan beberapa penelitian, pengunaanPhET Interactive Simulation sebagai media virtual memberikan pengaruh yang berbeda dibandingkan dengan pengunaan media real. Hal itu dibuktikan dengan ditemukan bahwa peserta didik yang belajar dengan bantuan laboratorium virtual memperoleh skor tes penguasaan konsep [11] dan prestasi belajar [13] lebih baik dibandingkan dengan peserta didik yang bekerja 
di laboratorium fisik yang biasa.Pada beberapa penelitian lainnya, seperti tentang konsep rangkaian juga membuktikan bahwa peserta didik yang mengunakan PhET statistik performa lebih baik nilai rata-ratanya dibandingkan dengan peserta didik yang mengunakan peralatan real [16].

Walaupun sebagian besar penelitian membuktikan pengunaan PhET memberikan pengaruh yang lebih baik daripada pengunaan laboratorium nyata, namun penelitian lainnya juga ada yang mendapatkan bahwa tidak ada perbedaan yang signifikan antara pengunaan PhET dibandingkan dengan mengunakan laboratorium nyata [20]. Akan tetapi ada kontribusi yang berbeda, dimana peserta didik pada kelompok yang mengunakan simulasi tidak perlu menghabiskan waktu yang banyak pada aktivitas yang berhubungan dengan pekerjaan laboratorium dan masalah yang berhubungan dengan teknik dan kerja manual, sehingga peserta didik bisa lebih banyak waktu untuk berpikir, menganalisis, dan membahas [20].

Dari beberapa penelitian tersebut sebenarnya pengunaan media PhET sangat tepat dikolaborasikan dengan percobaan riil. Hal ini dikarenakan PhET memberikan kemudahan dalam pemanapan konsep. Selain itu, PhET juga efektif sebagai penganti laboratorium rill. Menurut [12] dalam kondisi yang tepat, simulasi dapat sangat efektif mengantikan peralatan laboratorium nyata.Namun demikian tidak disarankan bahwa simulasi selalu,

\section{Kesimpulan}

Berdasarkan paparan dan pembahasan yang telah diuraikan dapat disimpulkan bahwa $\mathrm{PhET}$ mengandung model-model konseptual fisis yang mudah dimengerti oleh para peserta didik. PhET dapat dikolaborasikan dengan percobaan riil, maupun dapat digunakan sebagai penganti laboratorium rill. Simulasi ini dapat membantu peserta didik dalam mengenal topik baru, membangun konsep atau skill, memperkuat ide, menyediakan hasil akhir dan refleksi serta menyediakan visualisasi umum antara peserta didik dan guru. Selain itu juga hasil dari beberapa penelitian menunjukkan bahwa pengunaan PhET memberikan pengaruh yang berbeda dari segi penguasaan konsep, hasil belajar dan kemampuan pemecahan masalah peserta didik, karena PhET dapat menjelaskan konsep yang abstrak dan dalam pengunaannya tidak memerlukan waktu yang banyak.

\section{Kepustakaan}

[1] Sherin, B, Common Sense Clarified: The Role of Intuitive Knowledge in Physics Problem Solving, Journal Of Research In Science Teaching, Vol 43, No 6, 2006, pp 533-555.

[2] Docktor \& Mestre, Synthesis Of Discipline-Based Education Research In Physics. Phys. Rev. ST. Phys. Educ. Res, Vol 10, No 020119, 2014.

[3] Clement, John, Student Preconceptions In Introductory Mechanics. Am. J. Physics, Vol 50, No 1, 1982 , pp 66-10.

[4] Tuminaro, J \& Redish, E, Elements of a cognitive model of physics problem solving: Epistemic game. Phys. Rev. ST. Phys. Educ. Res, Vol 3, No 020101, 2007.

[5] Etkina, E, Pedagogical Content Knowledge and Preparation Of High School Physics Teachers. Phys. Rev. ST. Phys. Educ. Res, Vol 6, No 020110, 2010.

[6] Cokc, D. M, Representation Use And Strategy Choice In Physics Problem. Phys. Rev. ST. Phys. Educ. Res, Vol 8, No 020117, 2012.

[7] Bell, T., Urhahne, D., Schanze, S., Plouzhner, R, Collaborative Inquiry Learning: Models, Tools, And Challenges. International Journal of Science Education, Vol 32, No 3, 2010, pp 349-377.

[8] Odom, A.L., Marszalek, J. M., Stoddard, E. R \& Wrobel, J. M, Computers and Traditional Teaching Practices: Factors influencing middle level students' science achievement and attitudes about science. International Journal of Science Education (IJSE), Vol 33, No 17, 2011, pp 2351-2374.

[9] Wieman, C.E., Adam, W. K., Loeblin, P \& Perkins, K. K. 2010. Teaching Physics Sing Simulations Phet Simulations.The Physics Teacher, (Online), 8 : 225-227, (http://scitation.aip.org), diakses 17 April 2016.

[10] Moore, E.B., Herzog, T. A \& Perkins, K. K, Interactive Simulations As Implicit Support For Guided-Inquiry. Chem. Educ. Res. Pract, vol 14, 2013, pp 257-268.

[11] Zacharia, C.Z \& Jong, D.T, One Specific Advantage For Virtual Laboratories That May Support The Acquisition Of Conceptual Knowledge Is That Reality Can Be Adapted To Serve The Learning Process. Reality Can Be Simplified By Taking Out Details, Cognition and Instruction, Vol 32, No 2, 2014, pp 101-158.

[12] Farrokhnia, M.R \& Esmailpour, A, A Study on The Impact of Real, Virtual and Comprehensive Experimenting on Stdents' Conceptual Understanding of DC Electric Circuits and Their Skills in Undergraduate Electricity Laboratory. Procedia Sosola and Behavioral Science, Vol 2, 2010, pp 5474-5482. 
[13] Martinez, G., Naranjo, F. L., Perez, A. L \& Suero, M. I, Comparative Study Of The Effectiveness Of Three Learning Environments: Hyper-Realistic Virtual Simulations, Traditional Schematic Simulations And Traditional Laboratory, Phys. Rev. ST. Phys. Educ. Res, Vol 7, No 020111, 2011.

[14] Okimustava., Ishafit., Suwondo, N., Resmiyanto, R \& Praja, A, Pengembangan Kuliah Eksperimen Fisika dengan Teknologi Multimedia, JRKPF UAD, Vol 1, No 1, 2014, pp 1-4.

[15] Finkelstein, N.D., Adam, W. K., Keller, C. J., Kohl, P. B., Perkins, K. K.,Podolefsky, N. S., Reid, S, When Learning About The Real World Is Better Done Virtually: A Study Of Substituting Computer Simulations For Laboratory Equipment. Phys. Rev. ST. Phys. Educ. Res, Vol 1, No 010103, 2005.

[16] Perkins,K,. Adam, W., Dubson, M., Finkeilstein, N., Reid, S., Wieman, C, Lemaster, R, PhET: Interactive Simulations for Teaching and Learning Physics, The Physics Teacher, Vol 44, 2006, pp 18-23.

[17] Adams,W.K, Student Engagement And Learning With Phet Interactive Simulations, US : Department of Physics University of Colorado, 2010.

[18] Rehn, D. A., Moore, E. B., Podolefsky, N. S \& Fineilstein, N. D, Tools For High-Tech Tool Use: A Framework And Heuristics For UsingInteractive Simulations. Journal of Teaching and Learning with Technology, Vol 2, No 1, 2013, pp 31-55.

[19] Podolefsky, N.S., Perkins, K.K \& Adams, W.K, Factors Promoting Engaged explorations with Computer Simulations.Phys. Rev. ST. Phys. Educ. Res, Vol 6, No 020117, 2010.

[20] Ajredini, F., Izairi, N., Zajkov, O, Real Experiments versus Phet Simulations for Better High-School StudentsUnderstanding of Electrostatic Charging, European Journal of Physics Education, Vol 5, No 1, 2013, pp 59-70. 